\title{
Vocational Art Design Education of School-enterprise Cooperation Model
}

\author{
Shiwei $\mathrm{Chi}^{1}$ Zhuo Chen ${ }^{2}$ Tiejun $\mathrm{Wu}^{3}$ \\ ${ }^{1}$ Sch. Of Digital Media, Shenzhen Institute of Information Technology \\ ${ }^{2}$ Dept. of Art Design, Dongguan Polytechinic \\ ${ }^{3}$ Dept. of Mechanical and Electronics Engineering, Dongguan Polytechinic
}

\begin{abstract}
Talents training mode of schoolenterprise cooperation in higher vocational education is double win mode promoting school development and highlighting the business interests. Tying features of Shenzhen, this paper studies building the path to conduct a preliminary exploration based on analyzing the inevitability, feasibility and existence on the basis of school-enterprise cooperation.
\end{abstract}

Keywords: School-enterprise cooperation, Talents training model, Art design education

\section{Introduction}

About training of design talents, there are many successful cases in the developed countries of the west. For example, dual system university mode of Germany, technical preparation system in USA, work-study alternate forms in England, and so on. These model all underlined close connection and cooperation between school and enterprise. Higher vocational art design specialty are trying to use the open teaching means, construct all types of outside-school practice base, and develop practice teaching activities with enterprise at present. But these patterns are still in the primary stage of schoolenterprise cooperation. Vocational education reform of art is mainly driven by market, enterprise and society.

\section{The necessity of school-enterprise cooperation of higher vocational art design education about Shenzhen}

As the frontier city of Chinese Reform and Opening, Shenzhen firstly started developing modern design. It has been the birthplace of China's modern design concept in the 1980s. Now there has been native design strength with strong ability in Shenzhen. In 2008, Shenzhen was the first city in China which wined the honorary title of Design Capital of the United Nations KeJiaoWen Organization. Based on the culture supporting strategy, Shenzhen has realized the transition creatively with the design means. Shenzhen has formed a good social atmosphere of respecting creativity and advocating design. These provide the development of art design education with a favorable external environment and create large demand for innovative design talents. But education model of higher vocational art design does not match with design industry development. The graduates cultivated in Shenzhen do not nearly meet with the requirements of design industry development.

There is a big difference in education patterns between higher vocational art design education and common higher education of academic type. On the one hand, it belongs to applied education the cultivated students have the practical operation ability for a specific project and the coordination capacity during project 
execution; on the other hand, it is different from common technical education, the cultivated student has the deeper cultural cultivation and acute artistic sensibility besides the ability of completing a design project by himself. It is the requirement that the training of art design talents should not be dependent on work behind closed doors in undergraduate school or short-term training in company. It must go the way of the combination of school and enterprise [1-3]. Now, there is a lack of effective modes with the requirements of trendy and reality in school-enterprise cooperation of higher vocational art design education. There is a big gap in depth, form and performance between our model and mature model in America, Germany. Higher vocational art design education of Shenzhen should target at training top skilled talents for economic and social development of Shenzhen. It will realize the goal of " triple win" among school, enterprise and student. It also provides a reference model in which local higher vocational school should serve regional economy and culture construction.

\section{The feasibility of school-enterprise cooperation of art design education}

\subsection{Policy Support}

In Guangdong province education development planning from 2011-2015, it is planned that Guangdong will forge an scholastic alliance with enterprise for vocational education, push forward schoolenterprise cooperation regulations of Guangdong vocational education, create a cooperation platform for vocational education and industry communication, establish security mechanism of schoolenterprise cooperation, complete " one hundred schools and one thousand enterprises " cooperation platform. The development plan encourages enterprise- owned school, park school, construction of enterprise campus and teaching factory. It encourages enterprises and workshops to enter the school. It inspires vocational schools to improve their own ability for serve enterprise development through product research, technical tackle, consultation service, and so on. These will mainly drives design companies to intervene in school-enterprise cooperation.

\subsection{Cost savings}

To a design corporation, he should think about cost when a design corporation receives business. Design director and designer for school students or graduates, they are not competent do these jobs. So these two human costs are not to be saved. But design production staff can be replaced by students, and the cost of students is lower than costs of full-time staff. To some extent, the operating costs are reduced. For another form, the design corporation gives the design project to schools, higher vocational schools will organize students to complete the basic design project. Relatively excellent design will be picked out and deepened. In this way, the design corporation do not only saves operating costs, but also get some design. Although students' designs are immature, so many relatively excellent creativities are what design corporation. If design department of cooperation is placed in schools, design corporations can get abundant high quality human resources by training, and save location rent. These do help the development of design corporations.

\subsection{Selection and reserve of talents}

A real quality of a corporation is his talents. Design corporations can pick out excellent talents from higher vocational students through school-enterprise cooperation, and these potential students will be trained as talents reserve. In the pro- 
cess of cooperation, design corporations has enough time to discover talents; in the process of training, these latent staff will receive and identify with enterprise culture little by little. in comparison with recruiting new employees on the job market, risk and costs of this pattern is lower.

\section{The Difficulties of School- Enterprise Cooperation for Art De- sign Education}

\subsection{The Difference in School- Enterprise Operation Model}

There are many problems for student practices of art design specialty. These problems are caused by conflict of school-enterprise operation model. The trained students in school mainly aim at student employment, while corporation operations mainly aim at economical interests. And that is the difficulty. Design corporations can run normally without practice student. Higher vocational students can not fulfill internship if higher vocational schools are independent of corporations $[4,5]$. In the process of designing specialty talents training scheme, based on what the job needs, the abilities and qualities are decomposed, training goal and teaching program are determined. Every course has some ability and quality that corresponds to the job. There are some methods for example, project importing method, task decomposition method, and so on. In horizontal comparison with corporation operation pattern, these methods still do not jump out the traditional education pattern. It is not reality that corporation operation pattern will carter for school education model. Corporation only operation carters for market demand. In the game of the two patterns, higher vocational schools are always passive. Since design corporations do not change, education model have to change.

\subsection{Lack of Teachers}

The computer art design specialty has seven full-time teachers in Shenzhen Institute of Information Technology and fourteen part-time teachers. Thereinto, three full-time teachers have technician qualification; the number of teacher imported from corporation is zero; the seven full-time teachers all have above six months work experience. From the perspective of the data, all the full-time teachers is come from college graduates, and are short of work experience. These full-time teachers lack deep understanding on production technology, product development experience. Their skill levels and practice guidance abilities are therefore limited. At the same time, the part-time teachers are short of teaching experience. So they are weak in teaching organization and class management. This caused phenomenon of poor classroom discipline. And these part-time teachers tend to be technical personnel for corporation. It is difficult to solve corporationschool dilemma. That brought new problems for stable teaching order and teaching management.

\subsection{Small Acceptance Ability of De- sign Corporations}

Design corporations belong to knowledge-intensive industry with additional value. Unlike other human laborintensive industries, design corporation scale is smaller. Its number of employees is less than twenty, and these employees also include salesman, accountant, and so on. So the number of employee engaging in design is still less. It is difficult for design corporations to receive students who want to be interns. Generally, a design corporation can receive three to five students. It needs a certain amount of design corporations to support internship, if higher vocational schools uniformly arrange for students to do internships. For 
these reasons, students' contact with design corporations is as the main way, recommend arrangement of schools is as the supplementary way in practice. For example, the students majoring in art design in our department is distributed across a dozen corporations. It is impossible for schools to supervise and manage every student effectively in the course of internship. There are two reasons. Firstly, there is no way to arrange a full-time teacher in every corporation; secondly, it is difficult to depend on supervision of part-time teachers.

\section{Construction of the Path to School- Enterprise Model}

\subsection{Constructing Triple-Win Plat- form of School-Enterprise Model}

Under the guide of the competent department of the government, Services and Management Committee of Digital Media Art will be set up in cooperation with design corporations; school-running system will be tried out through government, school, corporation and association; triple-win running system of schoolenterprise cooperation will be explored and established; teaching, practice, research, design management, social service, five in one will be carried out (shown in Fig.1).

\subsection{Establishing in-School Joint- Stock Studio}

Art design specialty has establishing several in-school training bases, for example, Jiaoyang Design Studio, Zhong Nanxing Design Studio, and so on. These design studios have realized five in one, teaching, training, identifying, productive practical training, product research. On the one hand, Professional backbone working on the front line will be sent as part-time teachers, they will help to improve practice ability and specialty skill of higher vocational students; on the other hand, design studio affiliated to design corporations will be placed in shool, higher vocational schools provide space with rent free or cheaper rent, running costs will be lowered sharply through students' participation. School-enterprise cooperation will not stay only in the form of school project support, training students, providing training base. it is emphasize more on joint-stock cooperation system with benefit and risk sharing.

\subsection{Training double-competency teachers}

On the one hand, the teacher enterprise experience project will be actively promoted for improving double-competency of full-time teachers. It is required for full-time teachers to complete enterprise exercise task more than six months during the three years. Reviewing project before enterprise practice, inspecting in the process of enterprise practice, examining and certifying after enterprise practice, the whole process management will be carried out. Based on job related to their field of study, higher vocational schools will create a scheme of enterprise practice with the related to corporations, the scheme should explicitly define task of enterprise practice, these practice teachers are encouraged to develop research cooperation with design corporations, schools and corporations will supervised and examined enterprise practice of full-time teachers. On the other hand, technical backbone as the body, construction of part-time teachers will be strengthened. Schools and corporations will explicitly define construction objectives of part-time teachers and make requirements for quality and quantity of part-time teachers dispatched by corporations. Resource library of part-time teacher optimized project will be propelled, professional technical talents in the first-line production meet the needs of 
practice teaching that are received, interim regulations of part-time teachers administration will be completed, helping each other system will be set up, a fulltime teacher teaching same or similar

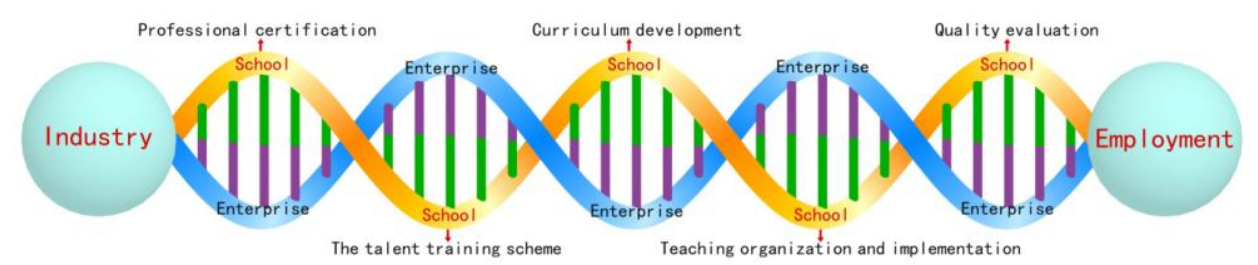

Fig. 1: Pattern graph of school-enterprise cooperation.

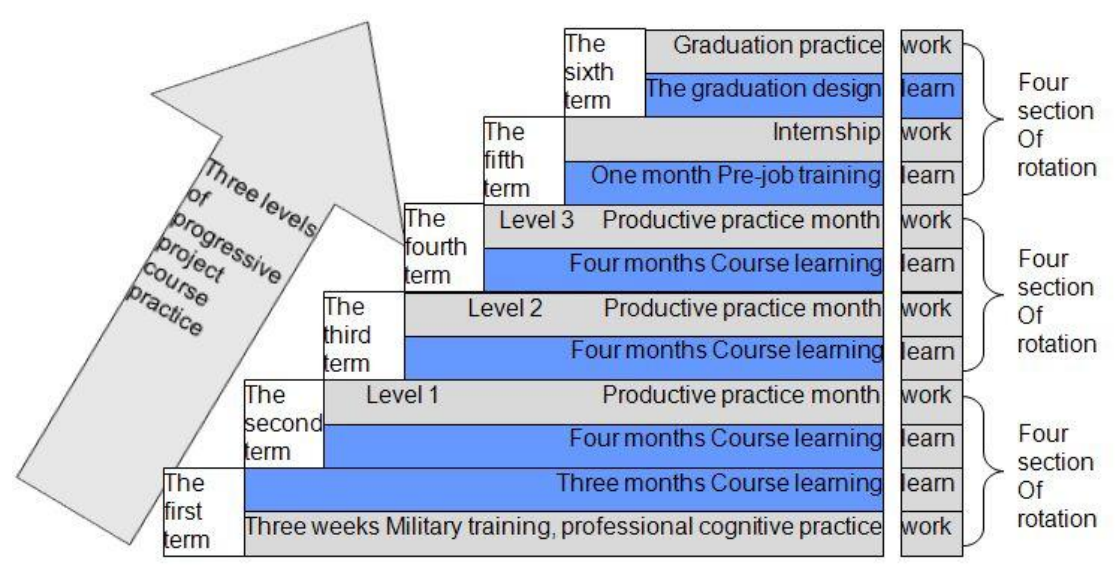

Fig. 2: Working and learning alternation organizational schemes of teaching.

courses will be assigned to every parttime teacher, teaching method of parttime teachers will be continually trained to improve their teaching abilities.

\subsection{Implementing Working and Learning Alternation Organiza- tional Schemes of Teaching}

In the teaching division, full-time teachers mainly teach culture quality courses, basic special courses and theory courses, and part-time teachers mainly teach specialized skill training courses [6]. In the organization and arrangement of teaching, firstly, working, learning, working, learning, teaching model of working and learning alternation is formulated; living space design training, public space design training, ancient building space, these training projects are used to accomplish training step-by-step; finally, pre-service training, internship, graduation project are used to improve employment ability of higher vocational students(shown in Fig.2).

\section{Establishing Safeguard Mechanism of School-Enterprise Cooperation}

Shenzhen Institute of Information Technology has opened administration office of school-enterprise cooperation. The main functions of the office is to make the school-enterprise school plan and optimize the allocation of resources, the office also coordinates and resolves the so- 
lution in the course of cooperation, administration regulations meet the requirements of cooperation should be set up, for example, administration methods for internship, interim administration regulations for cooperation in running schools, and so on. Evaluation and feedback system for school-enterprise cooperation projects will be established. The government will also set up a special fund to encourage corporations to cooperate.

\section{Summary}

About the present situation of the lack of design talents, this paper analyzed policy support, cost saves and selection and reserve of talent, studies on building talents training mode of school-enterprise cooperation. This mode should break through the plight of the difference in schoolenterprise operation model, less teachers and small acceptance ability, emphasize cooperation platform, teams of teachers and safeguard mechanism.

\section{Acknowledgements}

This research is supported by Major Project of Guangdong Higher Education Teaching Reform ([2007]154-17) and Education Project of Dongguan Polytechinicn (JGXM2011006, JGXM2011021).

\section{References}

[1] L.Z Lei: Vocational and Technical Education Vol. 19 (2012) No.15, p71. (In Chinese)

[2] Y.J Zhao: Adult Education Vol.31 (2011) No.8, p93. (In Chinese)

[3] J.C Ding: Education Development Research (2010) No.23, p76. (In Chinese)

[4] J. Wang, J.J. Wang: Chinese Vocational and Technical Education, Vol. 19 (2011) No.13, p36. (In Chinese)

[5] L.M. Shi: Education and Vocation Vol.32 Vol.7 (2008) No.9 p15. (In Chinese)

[6] C.D. Fu: Chinese Vocational and Technical Education Vol.16 (2008) No.9, p13. (In Chinese) 